\title{
Afinal, para que serve Filosofia Medieval?*
}

\author{
José Carlos Estêvão \\ Professor de História da Filosofia Medieval na USP.
}

\begin{abstract}
Resumo: 0 estudo de Filosofia Medieval, Abstract: The study of Medieval Philosoao contrário de um objeto de erudição, phy, instead of an object of erudition, uncompreende-se como história das condi- derstands itself as the history of the intelções de possibilidade intelectuais da Filo- lectual conditions of possibility of Modern sofia Moderna. A necessidade filosófica Philosophy. The philosophical necessity of das posições modernas, notadamente a modern positions, particularly that of Kant, de Kant, torna-se mais evidente pela cor- becomes more evident with the correct reta apreensão das aporias da Física e da understanding of ancient Physics' and Metafísica antigas reelaboradas pelos Metaphysics' aporias as reworked by escolásticos medievais. medieval Scholastics.
\end{abstract}

Todos lembram o famoso jogo de futebol filosófico do Monty Python. Jogam os gregos e os alemães. No time grego, Platão, Aristóteles, Plotino etc. No time alemão, Kant, Hegel, Nietzsche, Beckenbauer (é, o Beckenbauer...) etc. Marx está no banco. O juiz é Confúcio e os bandeirinhas são... Santo Agostinho e São Tomás...

Pois não é apenas uma boa piada. A Filosofia Medieval é mesmo um objeto de estudos bem estranho. Aliás, inventado muito recentemente. Durante tanto tempo se duvidou que houvesse mesmo Filosofia Medieval que um bom historiador de meados do século passado, Paul Vignaux, publicou, em 1938, com grande sucesso, um livro com o título O Pensamento na Idade Média (aliás, rapidamente traduzido aqui, em 1941). E só 20 anos depois o rebatizou como A Filosofia na Idade

\footnotetext{
* Este texto foi apresentado como abertura do primeiro seminário do Centro de Estudos de Filosofia Patrística e Medieval de São Paulo (CEPAME) na UFABC, no contexto das comemorações dos 20 anos do CEPAME, graças ao honroso convite da Profa. Cristiane Negreiros Abbud Ayoub. Mantendo seu caráter de exposição oral, abstenho-me de introduzir todas as notas e referências textuais que, de outra forma, seriam necessárias.
} 
Média". Note-se o cuidado com que ainda evitou falar em "Filosofia Medieval".

Com meio século de distância, em 1991, Alain de Libera jogou com o primeiro título de Vignaux, trocando o substantivo pelo verbo, ao publicar o seu Pensar na Idade Média ${ }^{2}$ (talvez o melhor livro de De Libera), mas agora sobre como nós concebemos, como pensamos, o pensamento medieval. Um percurso dos mais interessantes.

Mas nosso foco aqui não é nem a definição de "Filosofia Medieval", nem a história da História da Filosofia Medieval. É discutir algo como para que serve "Filosofia Medieval". Quer dizer, por que gastar o nosso tempo com isso.

Adiantando de imediato a resposta: estuda-se Filosofia Medieval para melhor compreender a Modernidade, ou antes, para entender a necessidade da Modernidade.

O ponto de partida é a lição do maior dos nossos historiadores da filosofia medieval, Étienne Gilson, que, já em 1922, havia publicado a primeira versão do seu La pbilosopbie au Moyen Âge, aliás, também evitando a expressão "Filosofia Medieval".

Como se sabe, Gilson começou seus estudos lendo Descartes (outra invenção recente, mas essa do Século XIX) e é a ele que devemos a melhor edição já feita do Discurso do Método. Foi assim que percebeu a necessidade de deslindar a teia de referências genéricas "aos escolásticos", na qual qualquer leitor de Descartes se embaraça desde a primeira leitura.

Tais estudos nos forneceram também dois livros insubstituíveis: o Index scolastico-cartésien (Paris: Vrin, 1912) e os Études sur le rôle de la pensée médiévale dans la formation du système cartésien (Paris: Vrin, 1930). Como diz a última frase, programática, do prefácio do segundo destes livros, "a bistória do pensamento medieval inclui a de sua influência, como a bistó-

1. Vignaux, P., La Pensée au Moyen Âge. Paris, Armand Collin, 1938. Vignaux, P., La pbilosopbie au Moyen Âge. Paris: Colin, 1958. Também imediatamente traduzido. A edição mais recente, creio, é La philosopbie au Moyen Âge. Précédé d'une Introduction autobiograpbique, et suivi de Histoire de la pensée médiévale et problèmes contemporains. Ed. par R. Imbach. Paris: Vrin, 2004.

2. De Libera, A., Penser au Moyen Âge. Paris: Seuil, 1991 (Pensar na Idade Média. Trad. P. Neves. São Paulo: Editora 34, 1999). 
ria do pensamento moderno a de suas fontes" (o que, diga-se de passagem, está bem longe do nosso guéroutianismo de tradição...).

Mas é um pouco mais do que isso: a compreensão dos medievais permite, como disse, entender não só as fontes da Modernidade, mas, em especial, a necessidade da Modernidade.

Porque estranho mesmo, à primeira vista, é o projeto moderno. Nada mais contra-intuitivo. Trata-se, como diz Kant, no Prefácio à Segunda Edição da Critica da Razão Pura, de proceder a uma nova Revolução Copernicana: Copérnico, diz Kant, "não conseguindo avançar muito na explicação dos movimentos celestes sob a suposição de que toda a multidão de estrelas girava em torno do espectador, verificou se não daria mais certo fazer girar o espectador e, do outro lado, deixar as estrelas em repouso" (B XVII) ${ }^{3}$. Então, "até hoje se assumia que todo o nosso conhecimento teria de regular-se pelos objetos", mas desse modo malograram todos os esforços e a metafísica nunca pôde trilhar o caminho da ciência, como o fez, há tanto tempo, a matemática, por exemplo. "É preciso", diz Kant, "verificar pelo menos uma vez, portanto, se não nos sairemos melhor, nas tarefas da metafísica, assumindo que os objetos têm de regular-se por nosso conhecimento" (B XVI). Repito: "os objetos têm de regular-se por nosso conhecimento".

Veja-se a enormidade da coisa: desde sempre se entendeu que conhecer é adequar o conhecimento ao que é conhecido. Ou, para dizê-lo no latim bárbaro da Escolástica Medieval: veritas est adequatio intellectus et rei (mal traduzindo, "a verdade é a adequação do intelecto às coisas"). Aliás, esta formulação lapidar é atribuída a Isaac Israeli, um autor egípcio de língua árabe e, evidentemente, de religião judaica, do Século X. Parece do mais evidente bom senso: o conhecimento é bom, é verdadeiro, na exata medida em que melhor reproduz ou representa, digamos assim (seja lá como for ou o que isso signifique), o que se quer conhecido. Pois Kant está propondo justamente o inverso: que "os objetos a serem conhecidos sejam regulados pelo nosso conhecimento". Realmente estranho.

Mesmo a Revolução Copernicana propriamente dita, isto é, abandonar a Teoria Geocêntrica em favor da Heliocêntrica, é contrária à mais imediata evidência sensível. Basta assistir ao pôr-do-sol: vemos o Sol se mover e é bem difícil provar que é a Terra que se move

3. Cito (e creio que é a primeira vez que isso acontece) a nova tradução de Fernando Costa Mattos. Petrópolis: Vozes, 2012. 
em torno do Sol, e não o contrário, como somos capazes de ver. Acreditamos nisso mas, de fato, prová-lo é outra história.

No entanto, sabemos, si muove, a Terra se move (e o Mundo também: o Prefácio à Segunda Edição da Crítica é de 1787, de dois anos antes da Revolução Francesa). Pois, do mesmo modo, devemos saber que não conhecemos, nem podemos conhecer as coisas (em si), mas tão só as coisas tais como se dão para nós: segundo as condições de possibilidade de conhecimento, transcendentais, de nossa sensibilidade e de nosso entendimento humanos, o que é longa e determinadamente mostrado por Kant na Crítica da Razão Pura (e, para o que mais for necessário, nas duas outras Críticas).

Mas, dado o caráter sistemático da obra, não há necessidade interna nem espaço teórico para expor geneticamente, historicamente, as causas do fracasso da metafísica. Ora, a História da Filosofia Medieval é justamente o nosso laboratório dos longos experimentos metafísicos fracassados que exigem a Revolução Copernicana, inclusive aquela preconizada por Kant.

Aliás, experimentos nem tão longos assim, pelo menos do ponto de vista histórico: o que chamamos de Filosofia Medieval (ao contrário da Longa Idade Média dos historiadores) pode muito bem caber em apenas dois séculos, de, digamos, 1142, data da morte de Pedro Abelardo, a 1347, data da morte de Guilherme de Ockham. Não é que antes ou depois disso não se tenha feito Filosofia durante a Idade Média, mas é nesse período que acontece o que foi determinante para caracterizar a produção filosófica de então como um momento específico da História da Filosofia e como um embate metafísico de novo tipo. Este período corresponde quase pontualmente ao da recepção latina de Aristóteles.

A Antiguidade sempre respeitou Aristóteles, mas ler mesmo que é bom, não leu muito, não. O número dos peripatéticos antigos é bastante reduzido em comparação com os defensores de outras, poucas, escolas filosóficas. Além disso, sua influência permaneceu fortemente confinada ao trabalho de eruditos escolares (no melhor sentido da palavra). No longo campeonato em que jogaram peripatéticos, estóicos, epicuristas e céticos de diversos matizes, a vitória coube, a partir do Século III, aos platônicos, ou melhor, como nós os designamos, aos neoplatônicos. Vitória das mais expressivas, pois estabeleceram uma hegemonia milenar, fosse em grego, em latim, em armênio, em 
árabe, em persa, em siríaco, em hebraico, em qualquer das línguas filosóficas de então.

Se Abelardo pode servir de marco para o início de um novo período é porque foi o primeiro - cuja obra chegou até nós - a pôr em xeque essa hegemonia e, simultaneamente, a intensificar em grande escala o interesse pela leitura de Aristóteles.

Acontece que Abelardo praticamente não leu, não pôde ler, Aristóteles (da Metafísica, tudo o que conheceu foi o título). Após os tempos de Boécio, no Século VI, o Ocidente desaprendeu o seu grego e Aristóteles esteve virtualmente "perdido", por seiscentos anos, para os latinos. A recepção começa com a tradução para o latim e seu início é tão veloz que um aluno de Abelardo, João de Salisbury, 37 anos mais novo do que ele, já pôde ler tudo o que Abelardo tinha que dar por "perdido", e será o primeiro medieval latino a fazer uma crítica frontal ao neoplatonismo ${ }^{4}$. Mas João de Salisbury não se torna peripatético e sim cético, declaradamente cético acadêmico, probabilista, segundo a lição de Cícero ${ }^{5}$. Ora, não é surpreendente que a leitura de Aristóteles induza ao ceticismo?

É que o ceticismo em filosofia, inclusive sendo de carteirinha, convive facilmente com o fideísmo em religião ("como a razão não pode conhecer, a vontade pode afirmar que... etc.."). E criticar o neoplatonismo podia parecer uma crítica à religião. O platonismo tardo-antigo, isto é, o médio-platonismo e o neoplatonismo, são contemporâneos e consubstanciais à ascensão e expansão do Monoteísmo e suas três grandes ramificações, o Judaísmo, o Cristianismo e o Islamismo.

O neoplatonismo de que Abelardo e João de Salisbury se distanciam é justamente, para nos restringirmos a uma única referência, o neoplatonismo por excelência dos latinos, o de Agostinho de Hipona,

4. Boehner, Ph., e Gilson, É., História da filosofia cristã. Trad. R. Vier. Petrópolis: Vozes, 19822, p. 332.

5. Sobre o ceticismo de João de Salisbury, ver Grellard, Ch., "Jean de Salisbury. Un cas médiéval de scepticisme" In Freiburger Zeitschrift für Pbilosopbie und Theologie, Freiburg, 54, 2007, pp. 16-40. Aliás, tema dos seminários com que ele brindou os membros do CEPAME, não há muito tempo, nos quadros de nosso Acordo USP-Cofecub, "Conhecimento e conhecimento de si. Contribuição das teorias do conhecimento na Antiguidade Tardia e na Idade Média a uma história do sujeito". 
isto é, bispo católico romano de Hipona, o autor das Confissões, do De magistro, do Da Trindade, da Doutrina Cristã, da Cidade de Deus. A própria expressão de uma ortodoxia cristã. E Abelardo, quando atacado, se apressa a dizer que nunca pretendeu trocar São Paulo por Aristóteles (literal e enfaticamente: Nolo, nolo sic esse philosopbus ut recalcitrem Paulo, nolo sic esse Aristoteles ut secludar a Christo $^{6}$ ), assim como João de Salisbury nunca pretendeu deixar de ser, ele também, cristão e, no fim de sua carreira eclesiástica, bispo de Chartres.

Aqui tocamos um dos temas que torna mais difícil a compreensão da Filosofia Medieval enquanto Filosofia propriamente dita: todos os seus autores são religiosos.

Ora, Filosofia e Religião são excludentes, metodologicamente excludentes: a Filosofia, por definição, só admite a argumentação racional e exclui qualquer concessão à autoridade (como já dizia Aristóteles paradigmaticamente: "sou amigo de Platão, mas mais amigo da verdade..."). A Religião, por sua vez, deve prescindir da razão e afirmar a autoridade (do "Livro" e/ou da hierarquia religiosa): o dogma expressa a revelação de um mistério inapreensível racionalmente e afirmado pela fé. Então, como ser simultaneamente filósofo e religioso?

Agostinho, principalmente Agostinho, elabora a questão de maneira extraordinariamente bem-sucedida. Leia-se, por exemplo (magno), o livro de Moacyr Novaes, A razão em exercício: estudos sobre a filosofia de Agostinbo ${ }^{7}$.

Antes de continuar é preciso lembrar que Agostinho, um autor do Século IV, não é, claro, medieval. Mas ele e diversos outros autores da Antiguidade Tardia são referências tão imediatas para os medievais que estes não são compreensíveis sem a leitura de Agostinho ${ }^{8}$, ou de

6. Confessio fidei ad Heloisam. Ed. Ch. Burnett, Mittellateinisches Jabrbuch, Suttgart, 31, 1986, pp. 147-155.

7. São Paulo: Discurso / Paulus, 20092. E, assim que possível, o recente A legitimação da razão: linguagem e vontade na filosofia agostiniana, que, junto com o novo livro de Lorenzo Mammì, Agostinho e as artes: dos diálogos filosóficos às Confissões, já devem estar no prelo.

8. Veja, a título de exemplo, o artigo de Gustavo Paiva sobre como não se entende o Aristóteles de Duns Escoto sem Agostinho: "One single yet manifold soul. Augustine's De trinitate and Aristotle's De anima in John Duns Scotus' doctrine of intellection" In Medioevo, Padova, 38, 2012, no prelo. 
Boécio, ou do Pseudo-Dionísio, entre outros. Além do que, todos são religiosos e da mesma religião (embora não do mesmo modo).

Ora, por que são religiosos? Mais ainda: por que praticamente todos (a ressalva é quase só retórica) - incluindo os que não são monoteístas, como Plotino e Porfírio - são religiosos?

O Cristianismo, sabemos (e o mesmo vale, em geral, para o Monoteísmo), não passa de platonismo para a plebe, como ensina Nietzsche. A desclassificação não é simplesmente por ser platonismo, já de si suficientemente indigno, mas porque nada é pior, para Nietzsche, do que o plebeu. No entanto, para tais autores da Antiguidade Tardia e da Idade Média - Ambrósio de Milão ou Jerônimo, Tomás de Aquino ou Ockham -, o que seduz é justamente a possibilidade de pôr a filosofia ao alcance de todos ${ }^{9}$, seja com a Filosofia completada e realizada pela Religião (como quer Agostinho), seja com a Filosofia posta a serviço da Teologia (como quer Tomás de Aquino).

Um pouquinho de História, e, neste caso, História Sagrada, para ilustrar o que é mesmo que significa aqui o "para todos":

"O tribuno romano mandou então recolher Paulo à fortaleza, ordenando também que o interrogassem sob açoites a fim de averiguar o motivo porque gritavam tanto contra ele. Depois de o amarrarem com as correias, Paulo observou ao centurião presente: 'Ser-vos-á licito açoitar um cidadão romano, ainda mais sem ter sido condenado?' A estas palavras, o centurião foi ter com o tribuno para preveni-lo: 'Que vais fazer? Este homem é cidadão romano!' Vindo então o tribuno, perguntou a Paulo: 'Tu és cidadão romano?' 'Sim', respondeu Paulo. O tribuno retornou: 'a mim me custou bom dinheiro comprar a cidadania'. 'Pois eu', disse Paulo, 'a tenho de nascença'. Imediatamente se afastaram dele os que iam torturá-lo". Atos dos Apóstolos, 22, 24-29.

Aliás, este número inteiro da revista é dedicado à Agostinho e sua recepção medieval.

9. Essa leitura, embora fuja à percepção comum, está muito longe de ser original. Citemos um único exemplo, particularmente interessante: Colish, M. L., Ambrose's Patriarchs: Ethics for the common man. Notre Dame: UP, 2005. O exato contrário da ética estóica, tão aristocraticamente exigente, tal como descrita por Pierre Hadot em La citadelle intérieure. Introduction aux Pensées de Marc Aurèle. Paris: Fayard, 1997. 
Não foi a única vez que São Paulo deu esta carteirada, sempre com grande efeito cênico. E vê-se bem a extensão dos privilégios do cidadão romano de então.

Ora, menos de 200 anos depois, a Constitutio Antoniniana do imperador Caracala, do ano de 212, estendeu a cidadania a todos os habitantes do Império Romano, tornando o que era privilégio (a gosto dos aristocratas) um direito universal (como preferem os plebeus), com sucesso tão intenso que a nós parece "natural" que ninguém possa ser privado de cidadania... São coisas assim que fazem Nietzsche chorar...

Pois é este o caldo de cultura em que vicejou o Monoteísmo. Assim como o mais influente da Filosofia Medieval não foi feito por scholars simplemente religiosos, mas expressamente por "mendicantes", defensores intransigentes e argutos da pobreza, em prol da qual argumentaram abundantemente.

Há, pois, boas razões filosóficas (dei apenas um exemplo, que parece suficientemente significativo) para defender que a Filosofia, de um modo ou de outro, tenha que se haver com a Religião, malgrado a natural antipatia entre elas.

Agora, isso, sem dúvida, dificulta nossa vida de leitores modernos. Conhecemos bons professores de filosofia que confessam nunca ter conseguido ler as Confissões. Mas, também, em defesa deles, vejamos como começa o livro:

"Tu és grande, Senhor, e muito digno de louvor.Grande é teu poder, e tua sabedoria é inumerável'. Quer te louvar o homem, pedaço qualquer de tua criação, e carrega em voltas sua mortalidade, carrega em voltas a prova de seu pecado e a prova de que tu resistes aos soberbos; no entanto, o homem quer te louvar, este pedaço qualquer de tua criação. Tu o incitas, para que goste de te louvar, porque o fizeste a caminho de ti e nosso coração é inquieto, até repousar em ti. Conceda-me, Senhor, saber e compreender se invocar-te é anterior ao louvar-te, e conhecer-te, anterior ao invocar-te. Mas quem poderia te invocar, se não te conhece? ..."10.

E etc. etc. etc. Essa lenga-lenga piedosa se arrasta por meia dúzia de páginas. Vejamos: "Tu és grande, Senhor". Allab arkbar! "Deus é grande"? Ora, o leitor nem sequer acredita em Deus. Se pretendemos que Agostinho seja filósofo, não seria melhor que começasse por

10. Uso a nova tradução de Lorenzo Mammì, ainda em elaboração. 
provar que Deus existe? "O homem, pedaço qualquer de tua criação"? Mas, que o mundo seja criado não passa de um dogma religioso indemonstrável. Aristóteles, ao contrário, prova que o mundo deve ser eterno, não podendo ter sido criado: por que o Agostinho filósofo não discute isso? Além disso, às voltas com o "pecado"? Francamente...

Tudo conversa fiada. Não é de estranhar que nosso professor tenha fechado as Confissões e voltado ao discurso claro e distinto dos modernos, em que Deus pode até ser provado, mas segundo a ordem das razões, lá pela Terceira Meditação, com direito a retorno e reforço do tema mais para frente, com a "louvação" simplemente sugerida como um interregno extrafilosófico. Ou, que Deus seja apenas pressuposto, embora não provado (o que seria impossível), mas só mais lá adiante, na Crítica da Razão Prática, já agora sem louvação nenhuma, garantido que a religião esteja bem circunscrita aos limites da simples razão.

No entanto, é pena que o professor não tenha se dado ao trabalho de continuar até perceber como vão se construído desde estas páginas iniciais das Confissões uma vigorosa crítica (de inspiração expressamente plotiniana) da concepção aristotélica acerca das categorias, justamente tematizando a noção de "grandeza", e um pesado ataque ao materialismo estoico. As indicações de uma inédita revisão das relações entre razão e linguagem ("compreender se invocar-te é anterior ao louvar-te, e conhecer-te, anterior ao invocar-te"), e, por certo, uma primeria e complexa teoria da vontade ${ }^{11}$ (sem a qual dificilmente se pode pensar em, quem diria, justo Nietzsche...).

Mas isso tudo já está aí, naqueles indigestos primeiros parágrafos que mais parecem uma litania sem muito sentido (e sem qualquer relevância filosófica)? Dê-se o tempo necessário à leitura de Agostinho' ${ }^{12}$, como aliás, o exige qualquer filósofo, que se verá que não foi nem por

11. Apenas para exemplificar: "nenhum leitor das Confissões negará que há sim em Agostinho um manejo inédito da noção de voluntas", como diz Isabelle Koch em seu texto apresentado no IV Colóquio do GT História da Filosofia Medieval e a recepção da Filosofia Antiga, "Sobre o conceito de voluntas em Agostinho". Discurso, São Paulo, 40, 2010, p. 93.

12. Não é o que faz Cristiane Ayoub ao mostrar como a boa compreensão de um único parágrafo de Agostinho pode exigir um livro inteiro? Cf. Ayoub, C. N. A., Iluminação trinitária em santo Agostinho. São Paulo: Paulus, 2010. 
acaso nem apenas por razões religiosas que Agostinho, este africano pardo de língua latina, veio a ser o filósofo mais lido da História...

Agora, que a religiosidade desses filósofos tardo-antigos e medievais nos incomoda, incomoda. Agostinho pelo menos escreve bem, mesmo que, às vezes, submetido a um cânon retórico que já não é o nosso, enquanto as infindáveis páginas dos escolásticos, na forma de intermináveis cadeias silogísticas, sobre, digamos, a linguagem angélica, podem, de fato, pôr à prova a paciência de qualquer um, como certos seminários recentes do CEPAME não nos deixam esquecer.

Voltemos aonde estávamos quando começamos a falar do caráter religioso dos filósofos medievais.

Repetindo: o primeiro intelectual latino medieval a ler o novo Aristóteles que chegava da Espanha (nota benne: da Espanha), João de Salisbury, recuou imeditamente para uma posição cética. Não era para menos: o primeiro aristotélico medieval (para usar a datação Ocidental), o espanhol de língua árabe Averróis de Córdoba, islâmico de religião, da geração imeditamente posterior a de Abelardo, percebeu claramente o quanto a perspectiva aristotélica se afastava do neoplatonismo em que se pensava o monoteismo, o amálga filosófico-religioso de então, abrangendo universos tão distantes quanto o do cristão romano Agostinho (do Século IV) e o do mulçumano persa Avicena (do Século XI), e propôs a diferenciação entre Filosofia, para os letrados, e Religião, para os incultos.

Filosoficamente consequente, mas politicamente suicida. Diga-se de passagem, Averróis, O Comentador por excelência de Aristóteles, só não comentou, porque nem mesmo leu, a Política de Aristóteles. Carência fatal.

Quando, mais tarde, Tomás de Aquino ataca violentamente o que chama de "averroísmo", o faz, expressamente, não em nome da Religião, mas em defesa da Ética (com maiúscula, a de Aristóteles) e da Política.

Aristóteles é extraordinariamente sedutor por, em primeiro lugar, fornecer um paradigma científico inegavelmente superior ao do neoplatonismo, que, na prática, eliminava qualquer possibilidade de ciência, em particular de ciência natural. Não por acaso, João de Salisbury é considerado o último dos mestres da Escola de Chartres, justamente aquela que mais intensamente se empenhou na possibilidade do desenvolvimento de uma ciência de inspiração neoplatônica 
antes da recepção de Aristóteles ${ }^{13}$. Em segundo lugar, pelo papel determinante da Ética e da Política. E mais, a obra de Aristóteles se constrói em confronto com o platonismo de primeira água, que conheceu do próprio mestre, portanto, com um arsenal crítico dos mais nutridos.

Malgrado as resistências (e as muitas proibições da censura eclesiástica, claro $\left.{ }^{14}\right)$, a hegemonia aristotélica se impõe quase completamente. Em especial quando Alberto Magno e seu grande aluno, Tomás de Aquino, lograram redefinir a compreensão intelectual do Cristianismo em chave antes aristotelizante (não exatamente aristotélica) do que neoplatônica (façanha não relizada nas duas outras grandes seitas monoteístas, apesar da excelência de seus filósofos). Note-se: quase se impôs completamente. O custo tanto do confronto com os neoplatônicos (cuja filosofia nasce de uma reação platônica ao aristotelismo, já armado contra ele) quanto da "conversão do Cristianismo" a uma acepção peripatética (portanto, com pretensões de ciência) exigiu uma revisão geral, inclusive do próprio aristotelismo, ou melhor, da metafísica em geral.

Enfim, estamos voltando ao nosso tema.

Pena que ainda falte uma digressão: o embate se deu na Escola. Isto é, na Universidade, portanto, entre especialistas, ambiente propício para os peripatéticos. Enquanto qualquer um (exceto alguns professores de filosofia) é capaz de ler as Confissões, pelo menos a parte aparentemente narrativa, certamente só um profissional é capaz de ler as mil páginas das Questões Sutilíssimas sobre a Metafísica, como diz o título tradicional, de João Duns Escoto ${ }^{15}$. O que não é sem consequências, porque a disputa não teve espaço para refugiar-se apenas

13. Vejam-se, por exemplo, os textos compilados em Lemoine, M., et Picard-Parra, C., éds., Théologie et cosmologie au XII ${ }^{\text {me }}$ siècle. L'École de Chartres. Paris: Les Belles Lettres, 2005. E a tradicional coletânea de artigos organizada por Wilks, M., ed., The World of Jobn of Salisbury. Oxford: Blackwell, [1984] 1997.

14. O recurso à autoridade exigido pela religião cobra seu preço: sobre a intensidade e virulência do controle exercido sobre os intelectuais medievais, consulte-se o brilhante livro de Luca Bianchi, Censure et liberté intelectuelle à l'université de Paris (XIII'-XIV'e siècles). Paris: Les Belles Lettres, 1999.

15. Para quem quiser se aventurar, está até traduzido: John Duns Scotus, Questions on the Metaphysics of Aristotle. Transl. G. J. Etzkorn and A. B. Wolter. New York: The Franciscan Institute, 1997. 2 vols. 
no terreiro religioso (como aconteceu, em particular, no caso da tradição mulçumana).

É verdade que o Cristianismo é platonismo para a plebe, e não houve jeito de inventar um "aristotelismo popular". O que se fez foi separar Filosofia e Religião, embora muito mais cuidadosamente do que na proposta de Averróis, que, afinal, tinha razão, com o seu mote de ciência para os homens de razão (rationabilis) e a religião para os homens apenas racionais (rationales) ${ }^{16}$. Separação que deu em Teologia, no caso de Tomás de Aquino, tema e termo aristotélicos que foi capturado pela Religião, mas com a contrapartida de, de certo modo, liberar tanto a metafísica de teias ontoteológicas (ou, o que é o mesmo, de evidenciá-las) quanto, em particular, afrouxar as amarras metafísicas tradicionais da física.

No caso de Guilherme de Ockham, recusando pela base o programa de Alberto Magno e Tomás, terminou em separação entre Razão e Fé. Ao custo tanto do irracionalismo da fé (que tanto tem nos custado até hoje) quanto da realidade da ciência (parece que Kant começa a assomar no horizonte...). O que traz a vantagem de desonerar ainda mais intensamente a física do lastro metafísico tradicional ("não, diz ele, a Física não é a ciência das coisas naturais"...) e, principalmente, pois foi aquilo no que melhor investiu sua vasta capacidade filosófica, desnaturalizar a ética e a política.

Não por acaso, estamos falando em separação, o próprio mote da Modernidade, que se define justamente pela autonomia das esferas.

Resumindo, o embate entre a recepção medieval de Aristóteles e a tradição neoplatônica se deu nos quadros profissionais da Escola, tendo como pano de fundo a relação com a Religião. Foi obra de gerações de especialistas escolásticos que, por seu fervor religioso, disputaram com enorme volume de argumentos, até as últimas consequências, acerca da concepção de metafísica.

Ao fim, nenhuma metafísica podia apresentar-se como ciência. Gradativamente, o aristotelismo perde terreno justamente para o ceticismo, como nos albores de sua recepção. De início, um ceticismo ainda não assumido, como o de Nicolau de Autrécourt ("nunca terá

16. Cf., em particular, Averróis. Discurso decisivo. Fasl al-maqal. Intr. A. de Libera. Tr. A. R. Hanania. São Paulo: Martins Fontes, 2005 (texto que, aliás, os latinos não conheceram). 
passado pela boca de Aristóteles uma proposição verdadeira") e de Bernardo de Arezzo (ambos ainda da geração de Ockham) ${ }^{17}$. Mais tarde, então com enorme sucesso, com o ceticismo da Douta Ignorância, de Nicolau de Cusa. Para culminar nos Ensaios de Michel de Montaigne, agora não mais apenas contra a ciência, mas, principalmente, contra o fideísmo (não por acaso, no auge das Guerras de Religião, que ensanguentam a Europa por 30 anos). Note-se que o rápido "interregno" cético do Renascimento dura quase tanto quanto o período de 200 anos de floração da Escolástica medieval.

O primeiro moderno a fazer o balanço geral do resultado, o espanhol Francisco Suárez, contemporâneo um pouco mais moço do renascentista Montaigne, dá início aos seis grossos volumes de suas Disputas Metafísicas, apontando como a metafísica, tal como pensada até então, simplemente carece de sistema (literalmente, "sistema", este mote moderno desconhecido pelos escolásticos) ${ }^{18}$. Mas, como a minuciosa revisão dos "Três Caminhos", o de Tomás de Aquino, o de João Duns Escoto e o de Guilherme de Ockham, não se mostrou redutível a sistema, restou que outro filósofo, este francês, propusesse começar tudo de novo, nas suas, não mais Disputas, mas Meditações Metafísicas. O método era outro.

Então, quando nos pomos a ler pela primeira vez, e pela ordem das razões, as Meditações Metafísicas, começo canônico dos nossos cursos de Filosofia, lá estão as referências genéricas "aos escolásticos", nas quais qualquer leitor de Descartes se embaraça desde a primeira leitura. O que é mesmo que quer dizer "realidade objetiva"?

Agora, depois de acompanhar o longo e trabalhoso processo filosófico que se inicia com a recepção de Aristóteles, em meados do Século XII, e sua contraposição à tradição neoplatônica, entendemos que a dúvida com que se iniciam as Meditações é tudo menos retórica: entendemos a necessidade (enfatizemos "necessidade") de cada um dos argumentos contra o conhecimento advindo dos sentidos (todos fartamente tematizados pela Escolástica ${ }^{19}$ ), as críticas às categorias

17. Cf. Nicholas of Autrecourt: His Correspondence with Master Giles and Bernard of Arezzo. Ed. L. M. de Rijk. Leiden: Brill, 1994.

18. Cf. Courtine, J.-F., Suarez et le système de la métapbysique. Paris: PUF, 1990.

19. Um único e notório exemplo: o artigo 6 da questão 84 da Primeira Parte da Suma de Teologia, "Se o conbecimento intelectivo é recebido das coisas sensiveis", diz, nas objeções (recorrendo à autoridade de Agostinho), que "de tudo o que senti- 
escolásticas (fartamente levantadas por eles mesmos, uns contra os outros), a necessidade da figura do Deus Enganador (não, ele não foi inventado por Descartes), do Cogito etc. etc. etc. Mais a necessidade de uma nova Física, cuja fundamentação, afinal, é a verdadeira pretensão de Descartes e a sua novidade, além, é claro, do método.

Da crise simultânea da Metafísica e da Física antigas (velha e boa tese de Alexandre Koyrée ${ }^{20}$ ) nasce, em primeiro lugar, uma nova Física, a nossa, a Física Moderna. Isto é, diz Kant, ainda no Segundo Prefácio: a Física que compreende "que a razão só entende aquilo que ela mesma produz segundo seu projeto, e que ela tem de colocar-se à frente, com os princípios de seus juízos segundo leis constantes, e forçar a natureza a responder às suas perguntas em vez de apenas deixar-se conduzir por ela" (B XIII).

Claro, só pode ser assim, porque, senão, incorreremos em todas as aporias tão minuciosamente disputadas pelos medievais.

Exemplifiquemos, fazendo pastiche de uma discussão "ockhamiana"21: "não, a Física não é a ciência das coisas naturais, é a ciência das proposições cujos termos supõem pelas coisas naturais". Como os termos supõem, substituem, na mente as coisas naturais? É que a intuição - mas que conceito é este para um aristotélico? - das coisas faz nascer, causa naturalmente no intelecto, o termo mental que é seu efeito. Sim, mas é possível, embora não provável, que se tenha intuição

mos pelo corpo, mesmo quando não estão presentes os sentidos, recebemos suas imagens, como no sono e na demência; ora, não somos capazes de distinguir pelos sentidos se sentimos os próprios sensíveis ou suas imagens falsas; mas nada pode ser estabelecido se não for distinguido do falso" etc. Portanto, conclui-se que "a verdade não deve ser esperada dos sentidos": Et sic concludit quod non est expectanda veritas a sensibus. A passagem citada por Tomás está na nona das 83 Questões, de Agostinho. Cito de acordo com a tradução de Carlos Arthur Ribeiro do Nascimento, inicialmente publicada nos Cadernos de Trabalbo do CEPAME, São Paulo, II(2), 1993, pp. 14-27.

20. Cf. Koyré, A., Do mundo fechado ao universo infinito. Trad. D. M. Garschagen. Rio de Janeiro: Forense, 2001. Id., Estudos de bistória do pensamento científico. Trad. M. Ramalho. Rio de Janeiro: Forense / UnB, 1982.

21. Já para uma abordagem correta, veja-se o texto de Carlos Eduardo de Oliveira, "Ockham e a teoria aristotélica da ciência", publicado nos anais do V Colóquio do GT História da Filosofia Medieval, por Alfredo Storck, In Aristotelis Analytica posteriora. Estudos acerca da recepção medieval dos Segundo Analíticos. Porto Alegre: Linus, 2009, pp. 177-206. 
de coisa não existente, então não é impossível que o termo mental não seja causado por uma coisa existente. E não, não temos critério de distinção. Ademais, a relação de causa e efeito não pode ser, não é, uma relação real ${ }^{22}$, então qual o fundamento de tal física tão distante das coisas? Ela não o tem e o termo "fundamento" não faz parte do léxico filosófico (sic). Então é uma lógica, digamos, uma hipótese sustentada pela coerência interna entre pressupostos e conclusões? Não, não é uma lógica, pois... etc. Ou então, de outro lado, diziam os chamados mertonianos, o melhor é calcular proporções, tarefa do fí$\mathrm{sico}^{23}$. Mas Aristóteles não proíbe misturar os gêneros? Ora, o objeto formal da matemática é distinto do da física, portanto... Sim, mas... Etc., etc.

De Averróis para frente, de meados do Século XII ao fim do Século XIV, nossas bibliotecas têm os comentários da Física de Aristóteles de 17 autores diferentes (podemos contar), um número bem pequeno em relação à totalidade dos comentários remanescentes (houve quem tenha contado, como Charles Lohr ${ }^{24}$ ), e deve ser fascinante compará-los, embora tão trabalhoso que, até hoje, salvo melhor juízo, ninguém o fez ${ }^{25}$. Pois foi neste embate que se reduziu a Física antiga (e medieval) às suas aporias intransponíveis (causa da percepção de Copérnico de que era necessário renunciar ao geocentrismo).

Tarefa puramente negativa? Não, porque sobrou a ideia de ciência e de ciência da natureza, uma extraordinária proeza que só vicejou nesta tradição, a nossa, a da Filosofia: sem a Física antiga e sua

22. Cf. o artigo de Carolina J. Fernández, nos anais do VI Colóquio do GT História da Filosofia Medieval: "Contingência e necessidade na causalidade externa segundo Ockham: argumentos para revisar a interpretação dominante", doispontos, Curitiba / São Carlos, 7(1), 2010, pp. 113-135

23. Caroti, S., et Souffrin, P., éds., La nouvelle physique du XIV siècle. Firenze: Olschki, 1997.

24. Lohr, Ch. H., "Medieval latin Aristotle commentaries", Traditio, New York, 1967-1974 (a mera descrição dos títulos, boa parte dos quais inéditos, se estende por quase 600 páginas)

25. Quanto a nós, só para a tradução dos prólogos (apenas dos prólogos) dos comentários filosóficos de Tomás de Aquino, fizemos um número interminável de seminários, cujo resultado, enfim está para ser publicado: Tomás de Aquino, Prólogos dos Comentários de obras de Aristóteles. Apresentação de Carlos E. de Oliveira. Introdução de F. Cheneval e R. Imbach. Trad. coletiva. São Paulo: Discurso / Paulus, no prelo. 
crítica medieval não haveria nenhuma Física Moderna. Nem Metafísica nem crítica da Metafísica. Nem Crítica da Razão.

Doutro ponto de vista, tomar a Filosofia Medieval principalmente como parte das condições de possibilidade da Modernidade, portanto, distinguindo-a categorialmente da Modernidade, mas integrando-a à gênese da Modernidade, é, sim, desqualificá-la. Não é por acaso que haja quem prefira falar em "Filosofia na Idade Média", ao invés de "Filosofia Medieval", pretendendo preservar uma certa, alguma, perenidade da Filosofia contra sua historicidade.

A Filosofia Medieval, assim como a Filosofia Antiga, estão tão mortas quanto a própria Antiguidade ou a Idade Média. Claro que é possível atualizar a obra de seus autores, como, por exemplo, Hannah Arendt faz com Agostinho (mesmo sendo de origem judia e não-religiosa) ou como Alasdair MacIntyre faz com Aristóteles (quer dizer, na verdade, com Tomás de Aquino). Ora, ainda que o resultado tenha inegável interesse filosófico, não parece ir além do campo das críticas conservadoras da Modernidade. Ou seja, estão, tanto quanto nós, na nossa mesma insuperável arena, a do nosso tempo histórico.

Esta exposição é um sobrevoo. Nada mais incorreto, dogmático e oco. Com certeza faz pensar que, para ser levada a sério, deveria mostrar, pela análise dos textos, cada uma de suas afirmações, cada passagem, a consistência das articulações, como é mesmo que se pode sustentar a remissão à História etc. etc. etc..

É verdade, mas esta é apenas uma celebratória exposição inaugural. A tarefa de conduzir corretamente o trabalho filosófico, segundo a relojoaria dos sistemas (ou das ordens arquitetônicas), ao microscópio e não ao telescópio como foi feito aqui, é tarefa coletiva e demanda o tempo necessário. Razão pela qual o trabalho de fato começa na sequência, quando, mais uma vez, nos voltamos para o texto mesmo de Agostinho (de Boécio, de Anselmo, de Abelardo, de Averróis, de Tomás de Aquino, de Henrique de Gand, de Duns Escoto, de Ockham). Não é assim, afinal, que no CEPAME temos usado nosso tempo há já vinte anos?

\section{Referências bibliográficas:}

ABELARDO. "Confessio fidei ad Heloisam". Ed. Ch. Burnett, Mittellateinisches Jabrbuch, Suttgart, 31, 1986.

AVERRÓIS. Discurso decisivo. Fasl al-madal. Intr. A. de Libera. Tr. A. R. Hanania. São Paulo: Martins Fontes, 2005 
AYOUB, C. N. A., Iluminação trinitária em santo Agostinho. São Paulo: Paulus, 2010.

BIANCHI, L. Censure et liberté intelectuelle à l'université de Paris (XIII -XIVe siècles). Paris: Les Belles Lettres, 1999.

BOEHNER, Ph., e GILSON, É., História da filosofia cristã. Trad. R. Vier. Petrópolis: Vozes, 1982.

CAROTI, S., et SOUFFRIN, P., éds., La nouvelle physique du XIVe siècle. Firenze: Olschki, 1997.

COLISH, M. L., Ambrose's Patriarchs: Ethics for the common man. Notre Dame: UP, 2005.

COURTINE, J.-F., Suarez et le système de la métaphysique. Paris: PUF, 1990.

DE LIBERA, A., Penser au Moyen Âge. Paris: Seuil, 1991 (Pensar na Idade Média. Trad. P. Neves. São Paulo: Editora 34, 1999).

FERNÁNDEZ, C. J., "Contingência e necessidade na causalidade externa segundo Ockham: argumentos para revisar a interpretação dominante", doispontos, Curitiba / São Carlos, 7(1), 2010, pp. 113-135.

GRELLARD, Ch., "Jean de Salisbury. Un cas médiéval de scepticisme", Freiburger Zeitschrift für Pbilosopbie und Theologie, Freiburg, 54, 2007

HADOT, P. La citadelle intérieure. Introduction aux Pensées de Marc Aurèle. Paris: Fayard, 1997.

KANT, I. Crítica da Razão Pura. Trad. F. Mattos. Petrópolis: Vozes, 2012.

$\mathrm{KOCH}$, I. "Sobre o conceito de voluntas em Agostinho". Discurso, São Paulo, 40, 2010.

KOYRÉ, A., Do mundo fechado ao universo infinito. Trad. D. M. Garschagen. Rio de Janeiro: Forense, 2001.

Estudos de bistória do pensamento científico. Trad. M. Ramalho. Rio de Janeiro: Forense / UnB, 1982.

LEMOINE, M., et PICARD-PARRA, C., éds., Théologie et cosmologie au XII ème siècle. L'École de Chartres. Paris: Les Belles Lettres, 2005.

LOHR, Ch. H., "Medieval latin Aristotle commentaries", Traditio, New York, 1967-1974.

NICOLAU DE AUTRECOURT, Nicholas of Autrecourt: His Correspondence with Master Giles and Bernard of Arezzo. Ed. L. M. de Rijk. Leiden: Brill, 1994.

NOVAES, M. A razão em exercício: estudos sobre a filosofia de Agostinho. São Paulo: Discurso / Paulus, 2009.

OLIVEIRA, C. "Ockham e a teoria aristotélica da ciência", In STORCK, A. (org.), In Aristotelis Analytica posteriora. Estudos acerca da recepção medieval dos Segundo Analíticos. Porto Alegre: Linus, 2009. 
PAIVA, G. V., "One single yet manifold soul. Augustine's De trinitate and Aristotle's De anima in John Duns Scotus' doctrine of intellection". In: Medioevo, Padova, 38, 2012.

SCOTUS, J. D. Questions on the Metaphysics of Aristotle. Transl. G. J. Etzkorn and A. B. Wolter. New York: The Franciscan Institute, 1997. 2 vols.

TOMÁS DE AQUINO, Prólogos dos Comentários de obras de Aristóteles. Apresentação de Carlos E. de Oliveira. Introdução de F. Cheneval e R. Imbach. Trad. coletiva. São Paulo: Discurso, no prelo.

TOMÁS DE AQUINO, "Suma de Teologia, Ia, q. 84". Trad. C. A. R. Nascimento, Cadernos de Trabalho do CEPAME, São Paulo, II(2), 1993, pp. 14-27.

VIGNAUX, P., La Pensée au Moyen Âge. Paris, Armand Collin, 1938.

. La pbilosopbie au Moyen Âge. Précédé d'une Introduction autobiographique, et suivi de Histoire de la pensée médiévale et problèmes contemporains. Ed. par R. Imbach. Paris: Vrin, 2004.

WILKS, M., ed., The World of Jobn of Salisbury. Oxford: Blackwell, [1984] 1997. 